\title{
Soil landscape evolution due to soil redistribution by tillage: a new conceptual model of soil catena evolution in agricultural landscapes
}

\author{
S. De Alba , M. Lindstrom , T.E. Schumacher , D.D. Malo
}

\begin{abstract}
This paper focuses on analysing tillage as a mechanism for the transformation of soil spatial variability, soil morphology, superficial soil properties and development of soil-landscape relationships in agricultural lands. A new theoretical two-dimensional model of soil catena evolution due to soil redistribution by tillage is presented. Soil profile truncation occurs through loss of soil mass on convexities and in the upper areas of the cultivated hillslopes; while the opposite effect takes place in concavities and the lower areas of the field where the original soil profile becomes buried. At sectors of rectilinear morphology in the hillslope (backslope positions), a null balance of soil translocation takes place, independent of the slope gradient and of the rate of downslope soil translocation. As a result, in those backslope areas, a substitution of soil material in the surface horizon with material coming from upslope areas takes place. This substituted material can produce an inversion of soil horizons in the original soil profile and sometimes, the formation of "false truncated soil". In the Skogstad agricultural field (Cyrus, MN) spatial patterns of soil properties (soil calcium carbonate content) in the surface soil horizons and soil morphology along several slope transects were analyzed. These spatial patterns are compared with those estimated for soil redistribution (areas of erosion and deposition) due to tillage using the Soil Redistribution by Tillage (SORET) model and water erosion using the models Water Erosion Prediction Project (WEPP) and Universal Soil Loss Equation (Usle2D). Results show that tillage was the predominant process of soil redistribution in the studied agricultural field. Finally, some practical implications of the proposed model of soil landscape modification by tillage are discussed. Nomographs to
\end{abstract}


calculated the intensity of the expansion process of the eroded soil units by tillage are proposed for three different patterns of tillage.

Keywerds: Soil redistribution; Tillage erosion; Water erosion; Soil catena; Soil spatial variability; Pedoturbation; Pedology; Mollisolls

\section{Introduction}

Unquestionably, søil redistribution by tillage plays a key røle in building and mødifying the geomorphølogy and pedology of sloping agricultural landscapes (Papendick and Miller, 1977; Govers et al., 1999). In recent years, high tillage erøsion rates have been

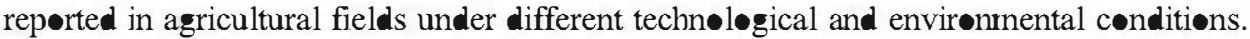
In many cases, for specific landscape pøsitions, tillage erøsion rates reached higher values than søil løss tolerance levels (Lindstrøm et al., 1992; G॰vers et al., 1996). First Lindstrom

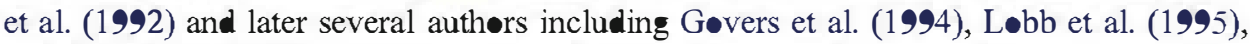
and De Alba (2003) have documented how tillage tends to produce a progressive denudation $\bullet$ r r lling landscapes. Fig. 1 shøws a widely accepted model $\bullet$ l løn-term ev॰lution $\bullet$ a complex sløpe prøfile as predicted by a simple simulation using a fixed søil transport rate by tillage operation. The rates of tillage soil translocation are proportional to the slope gradient, while the net rates of søil loss or gain are related to the morphølogy and

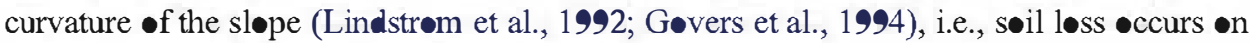
convex areas and deposition takes place on concave areas.

On the other hand, tillage contributes to the creation of distinctive landforms, such as, lynchets that form along field boundaries. Søil accumulates on the upslope side of field

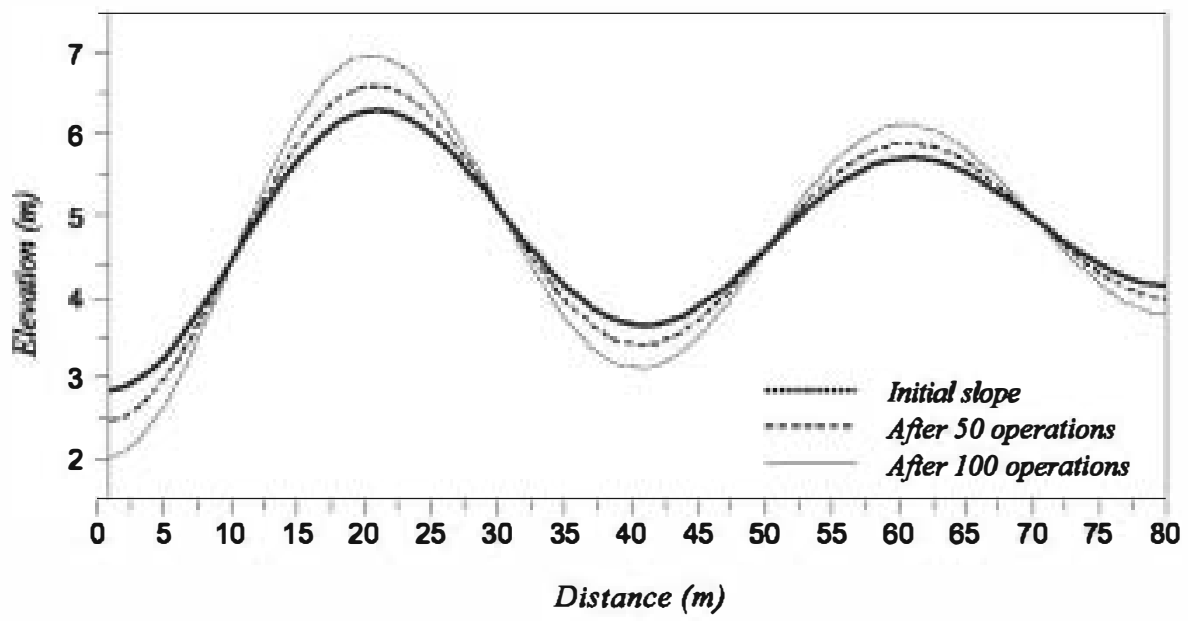

Fig. 1. Simulated long-term effects of soil redistribution by tillage on a theoretical slope profile. 
boundaries and soil is translocated away from the downslope side of field boundaries (Papendick and Miller, 1977). As a result, landscape benching takes place when boundaries between adjacent fields are located at backslope positions (e.g., De Alba, 2002) or if tillage is conducted between grass hedges (Dabney et al., 1999).

During the last decade, an increasing number of studies have been conducted to quantify søil translocation rates produce by different tillage implements and identifying contrølling factors Lindstrøm et a1. (1990,1992), Revel et a1. (1993), Govers et a1. (1994),

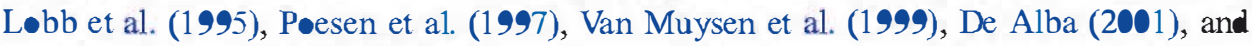
Torri and Borselli (2002). High soil translocation rates have not $\bullet$ ly been documented for modern tillage equipment using mechanical power, but as well for tillage practices using animal power (e.g., in Thapa et al., 1999). Quine et al. (1999) found that because tillage by

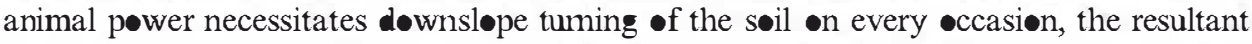
net downslope translocation may exceed the levels asseciated with tillage by mechanized power, in which the soil is tumed in $\bullet$ pposing directions on successive $\bullet c c a s i n n s$. Intense translecation rates and erosive effects due to manual tillage have been reported by Turkelbøom et al. (1999) in Thailand.

Regarding on-site effects of tillage erøsion on søil quality and productivity, Schumacher et a1. (1999) gave an example of how tillage erosion increases soil variability and degradation of surface søil quality in convex sløpe pøsitions, as well as increasing spatial variability of crop production. Torri et al. (2002) discusses how soil redistribution may cause modification of soil hydrology resulting in a complex series -f interactions and synergies between tillage and water erosion processes, as well as, with other geomorphic processes. Modification of søil slope stability due to søil accumulation $\bullet$ ver a possible surface of rupture can increase the risk of surface mass movement. There are few studies documenting the effects of soil redistribution by tillage on soil variability at field and landscape scales (e.g., Schumacher et al., 1999; Kosmas et al., 2001).

In this paper, we discuss the effects of søil redistribution on the spatial variability of søil prøperties, søil profiles, and søil landscapes. A new conceptual model of modification by tillage of the søil prøfile morphølogies and søil catenas is proposed. In order to identify field evidence of this model of soil modification, the spatial pattern - soil variability is analyze over an agricultural field that shows evidence of prior intense erosion. This soil pattern is compared with those predicted for tillage and water erosion to identify those erosion processes that had the predominant role in producing the current søil pattern. Finally, søme practical implications of søil landscape modification by tillage are discussed.

2. Modification of the soil profile morphology due to soil redistribution by tillage

\subsection{Mixing and inversion of the upper soil horizons by tillage using a moldboard plow}

At landscape positions where the thickness of the surface søil horizon is less than the depth of tillage, the plow layer comprises material from both the surface and the subsurface søil horizøns (e.g., shøulder pøsitions). As a consequence of this, moldbøard 


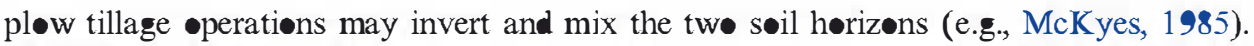
Fig. 2a shøws an idealized sketch of the inversion prøcess of søil hørizøns. At early stages after a few tillage operations, the plow layer presents contrasted components frøm tw॰ •riginal genetic hørizons (e.g., A and Bk hørizons in Fig. 2a). After repeated

a)

I-

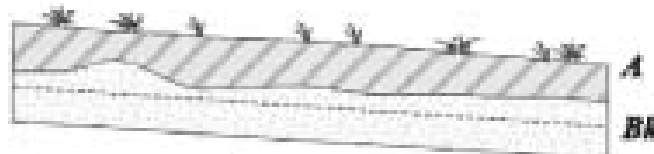

II-

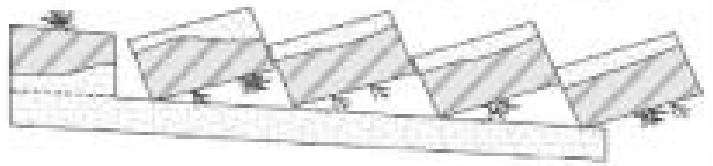

$A p(A / B k)$

\section{$B k$}

b)

I-

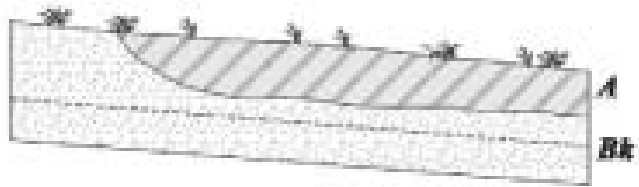

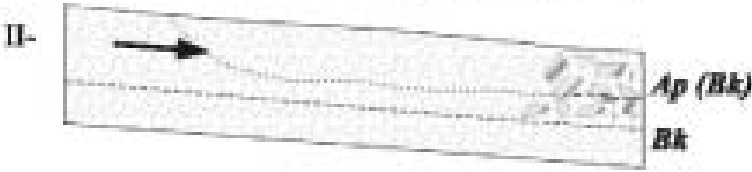

c)

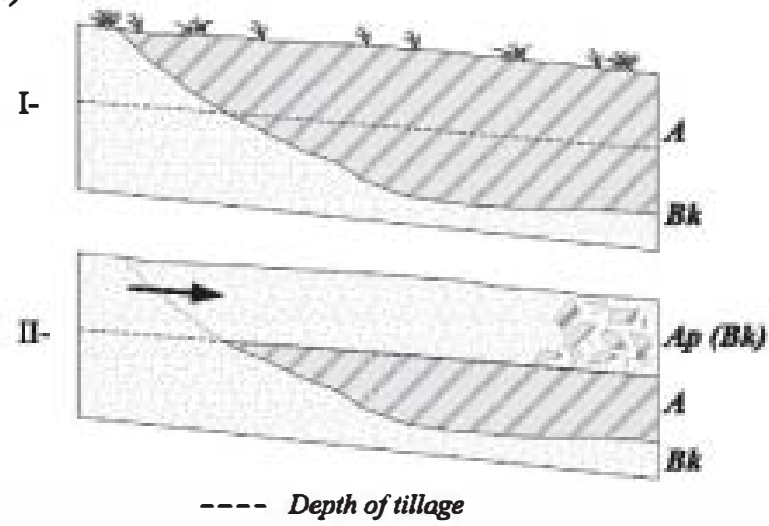

Fig. 2. Modifications of soil profile morphologies due to soil redistribution by tillage. Scheme of processes on three theoretical cases of soil profile: (a) mixing and inversion of the upper soil horizons; (b) substitution of surface soil horizon; (c) partial substitution of the surface soil horizon and fornation of a "false nuncate soil profile". The genetic horizon material composing the plow layer is shown in parentheses following the Ap symbol (I-before tillage; II—after tillage). 
tillage operations, the original differentiate components are mixed creating a homøgeneous plow layer (Ap horizøn). At this pøint, the properties of the final homogeneous søil horizon reflect the propørtions of the material from the two original horizons. Sibbensen and Andersen (1985) demonstrated the significance of the mixing -f soil constituents and developed a model to predict the mixing for long-term smallplot research. A more recent modeling apprøach is that of Van Oost et al., 2000.

\subsection{Soil profile truncation resulting from the loss of the upper soil horizon}

In general terms, søil redistribution by tillage produces a net søil loss on convexities and the upper part of the hillslopes. The medium- and long-term effects of such søil erøsion will result in the complete truncation of the søil prøfile by removing the surface søil hørizon or hørizons $(\mathrm{A}, \mathrm{AB}, \mathrm{Bw}$-r $\mathrm{Bt})$. At that pøint, material from an original subsurface genetic hørizøn (e.g., a Bk hørizøn in Fig. 2b) becomes directly expesed at the surface and constitutes the plow layer (Ap horizøn). In order to reveal the nature of the material that composes the new Ap hørizon, this horizon is designed as $\mathrm{Ap}(\mathrm{Bk})$ denoting within the parentheses the genetic horizon source of materials that constitute the plow layer.

\subsection{Soil profile truncation due to the substitution of surface soil horizons}

In backsløpe positions, where there may not be a net balance of søil loss or gain, the dominant soil transport process is tillage. The plow layer is transported downslope similar to the action of a conveyor belt from the top to the bottom of the sløpe. In backslope positions, when the søil prøfile presents a surface horizon shalløwer than the depth of tillage, a substitution of søil material in the surface horizøn with søil material transported from upslope positions takes place. The sketch in Fig. $2 \mathrm{~b}$ shows that soil

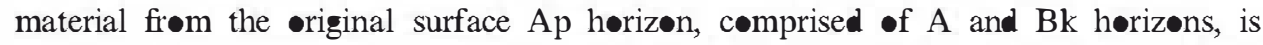
removed and transported downslope and replaced by subsurface horizon material (horizøn Bk) located upsløpe. The final soil profile is similar to that derived from søil truncation due to the loss by erosion of the upper søil horizøn. Nevertheless, there is a difference in that the søil truncation by substituting surface soil material is not related to a net loss of soil mass or lowering of the surface level.

\subsection{Formation of soil profiles with an inverted sequence of soil horizons: false truncated soils}

The partial substitution of the superficial søil hørizøns with søil being transløcated from upslope positions due to tillage can produce the formation of søil profiles, in which the original sequence of søil horizons becomes partially inverted. This is the case of soil profiles where the thickness of the surface horizon is greater than the depth of tillage. As represented in Fig. 2c, after repeated tilling, the upper part of the soil surface horizøn is substituted with material frøm a genetically different surface hørizøn located upslope; while below the plow layer, a portion of the original surface horizon remains unaltered by tillage. In the case represented in Fig. $2 c$, the soil profile at the 
bottom of the sløpe that initially has a sequence of genetic horizons of the type A-Bk is transforme to $\mathrm{Ap}(\mathrm{Bk})-\mathrm{A}-\mathrm{Bk}$, by partially substituting the original $\mathrm{A}$ horizon with søil material from Bk horizøn located upsløpe. This type of inverted søil profile can be called a "false truncated soil" because of its similarity at the surface level to an actual truncated soil formed by losing the surface horizons. In both cases, the upper surface hørizon after tillage corresponds to the original subsurface søil hørizøn (e.g., Bk in Fig 2c). Similar to what happens with the truncated type søils described in Section 2.3, the key mechanism to form this type of "false truncated søils" is søil transport by tillage and not a net balance of søil gain or loss.

\subsection{Soil profile buried due to the accumulation of material over the surface horizon}

Tillage causes a net søil gain $\bullet$ concavities and at the bott॰m of hillsløpes, giving place to the infilling of depressions and the formation of slope banks at the lower boundary of the fields. In the long-term, the original soil profile becomes buried under a deposit of material coming from upslope. In this case, the accumulated soil constitutes the new plow layer and its properties are related to those of the soil located upslope.

\section{Modification of the soil catena by tillage}

In addition to pedogenic processes and the action of soil degradation by water and aeclian erosion, søil redistribution by tillage represents another substantial mechanism that increases soil variability in sloping agricultural landscapes. A new conceptual model of søil catena evelution in sløping agricultural landscapes can be drawn based on the above-described mechanisms of soil profile modification by tillage.

An idealized transformation of a hypothetical soil catena due to soil redistribution by tillage is presented in Fig. 3. Before tillage, the initial hillslope presents a typical eroded soil catena (Fig. 3a) shøwing søil prøfiles with contrasting sequences of søil

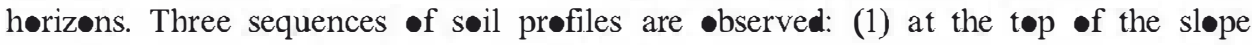
(shoulder), a truncated soil profile composed of a sequence of genetic horizons of the type $\mathrm{Ap}(\mathrm{Bk})-\mathrm{Bk}-\mathrm{C} ; 2)$ at backslope positions, a partially truncated soil profile with the horizon sequence of $\mathrm{Ap}(\mathrm{Bt})-\mathrm{Bt}-\mathrm{Bk}-\mathrm{C}$; and (3) at the bottom of the slope (footslope), the most complete soil profile composed of Ap(A)-A-Bt-Bk-C. As stated before, the Ap hørizøns are designed denøting between parentheses the genetic hørizøn søurce of materials that constitute the plow layer [(e.g., $\mathrm{Ap}(\mathrm{Bk})]$, to reveal the nature of the material which composes these surface horizons.

The accumulated long-term effects of søil redistribution by tillage are represented in Fig. 3b. The model shows that soil of the plow layer is gradually transported from the top to the bottom of the slope, and consequently the surface genetic horizons are expanded downslope along the plow layer. At the top and bottom of the hillslope, -pposite surface level changes take place corresponding to different net balances of søil loss and gain, respectively. As a result, a progressive søil truncation occurs in the summit and shoulder, while søil is buried in the føotsløpe and toesløpe. At backsløpe positions in Fig. 3b where the surface $\mathrm{Ap}(\mathrm{Bt})$ horizon is not as thick as the plow layer, 

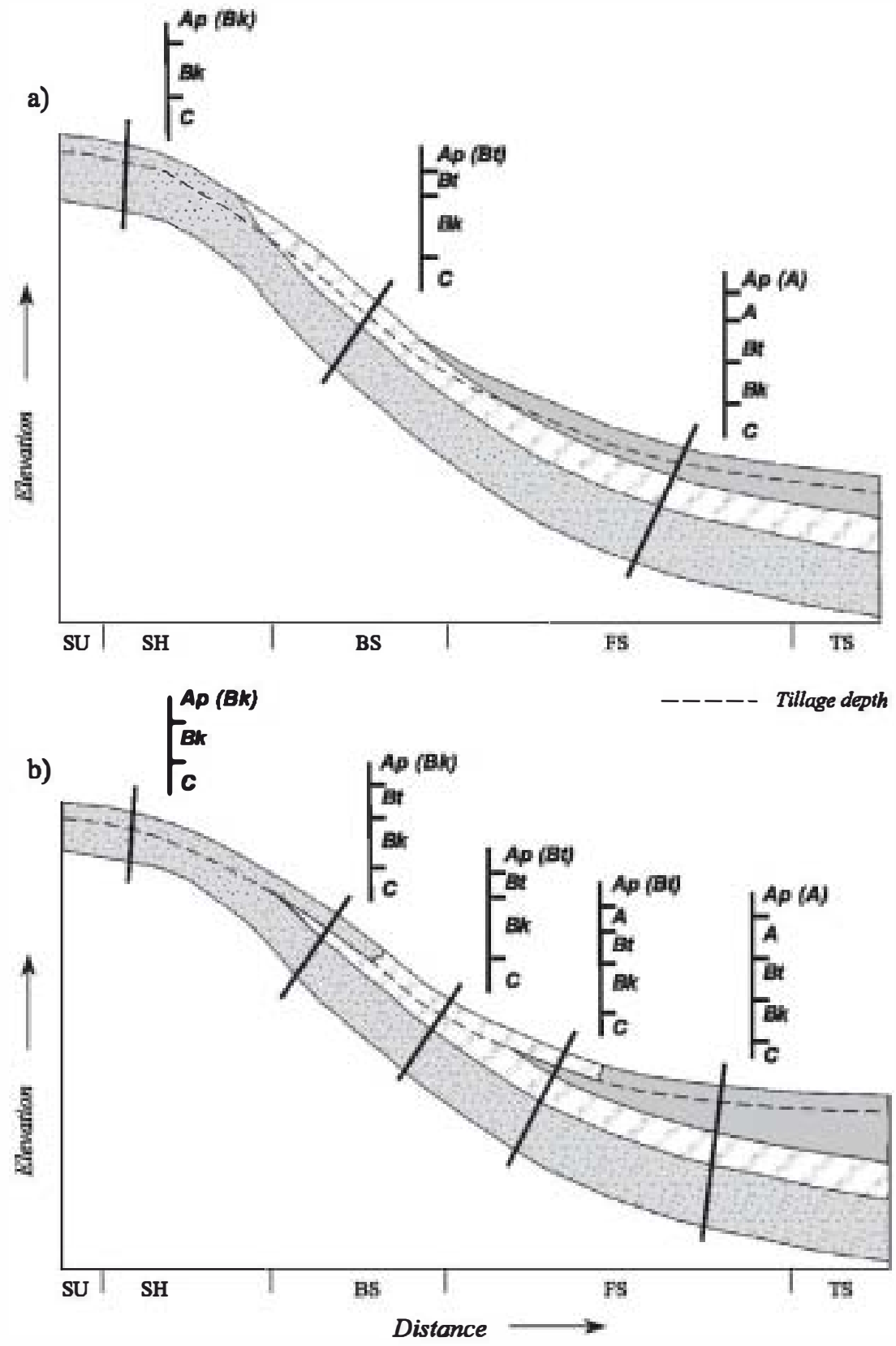

Fig. 3. Idealize model of soil catena modification by tillage. (a) Initial theoretical soil catena; (b) soil catena modified by soil redistribution to repeated tillage. The genetic horizon material composing the plow layer is shown in parentheses following the Ap symbol. Slope profile elements: $\mathrm{SU}=$ summit, $\mathrm{SH}=$ shoulder, BS=backslope, $\mathbf{F S}=$ footslope, TS=toeslope. 


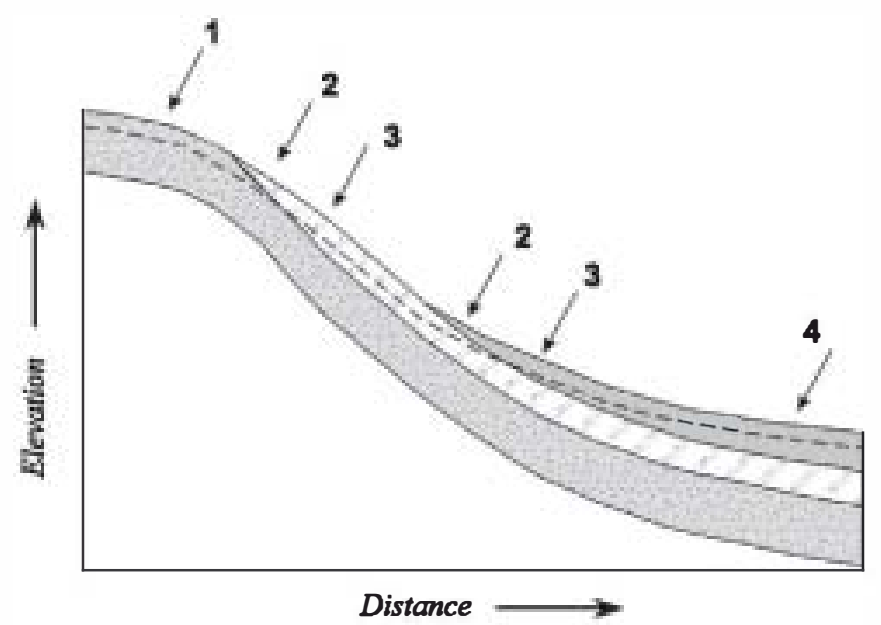

\section{1.- Soil truncation due to net soil loss}

\section{2.- Soil truncation by substitution of surface horizons}

\section{3.- Formation of soil profiles with a inverted sequence of genetic horizons: false truncated soils. \\ 4.- Buried soils due to net soil accumulation}

Fig. 4. Variability of mechanisms of soil profile modification by tillage along the slope.

the surface horizon is replaced with soil coming from upslope, resulting in the formation of truncated søil profiles of the types $\mathrm{Ap}(\mathrm{Bk})-\mathrm{Bk}-\mathrm{C}$. At backslope positions, where the originally surface horizon $\mathrm{Bt}$ is deeper than the plow layer, this horizon becomes only partially substituted causing the søil profiles to have an inversed sequences of horizøns. This is the case of profiles $\mathrm{Ap}(\mathrm{Bk})-\mathrm{Bt}-\mathrm{Bk}-\mathrm{C}$ or $\mathrm{Ap}(\mathrm{Bt})-\mathrm{A}-\mathrm{Bt}-$ Bk-C in Fig. 3b. Fig. 4 shows the distribution of the different processes of søil profile modifications produce by tillage along the original soil catena in Fig. 3a.

\section{Field evidence of soil catena modification by tillage: a case study}

An agricultural field with features of intense søil degradation by erosion was studied in order to identify patterns of søil variability. The expected patterns of søil redistribution by tillage and water eresion were determined. Then agreement in -bserved field variability between the twø søil redistribution processes was determined. In this approach, we used spatial variability of calcium carbonate as an indicator of prior soil redistribution. The proposed model of soil profile modification due to tillage is evaluated using a case study that examined the current soil variability over an agricultural landscape. 


\subsection{Materials and methods}

\subsubsection{Study area: the Skogstad field}

The study area was a 4-ha portion of a larger 16-ha field located north of Cyrus,

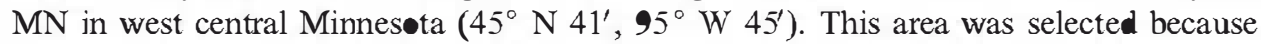
of its past management history of intensively based moldboard plow tillage and evidence of prior erosion (Lindstrom et al., 2000a). Prior erosion was identified by the exposure of calcareous subsøil material in the upper shoulder landscape positions. The landscape is characterize by a rolling topography with slopes up to $10 \%$. The climate is subhumid with approximately $600 \mathrm{~mm}$ of annual precipitation. The dominant soil catena in the study area was Svea (fine-løamy, mixed, superative, frigid Pachic Hapludolls)-Bames (fine-løamy, mixed, superactive, frigid Calcic Hapludolls)-Buse (fine-løamy, mixed, superactive, frigid, Typic Calciudells) was formed in Wisconsinaged glacial till. A topographic survey of the 4-ha portion of the field was conducted on a 10- by 10-m grid using a survey-grade Differential Global Positioning System (DGPS) to develop a digital terrain model (DTM).

\subsubsection{Spatial variability of soil calcium carbonate content}

Spatial variability of soil calcium carbonate content was characterized along three transects in the study area. Fig. 5 shows the location of the three transects in the study area DTM. Aløng each transect, 1.4-m depth soil profiles were described and sampled at $10-\mathrm{m}$ intervals. A separate transect was described and sampled in an adjacent noncultivated field. For this study, we analyzed the soil inorganic carbon content determine by the method of Wagner et al. (1998) and reported as calcium carbonate $\left(\mathrm{CaCO}_{3}\right)$ equivalent.

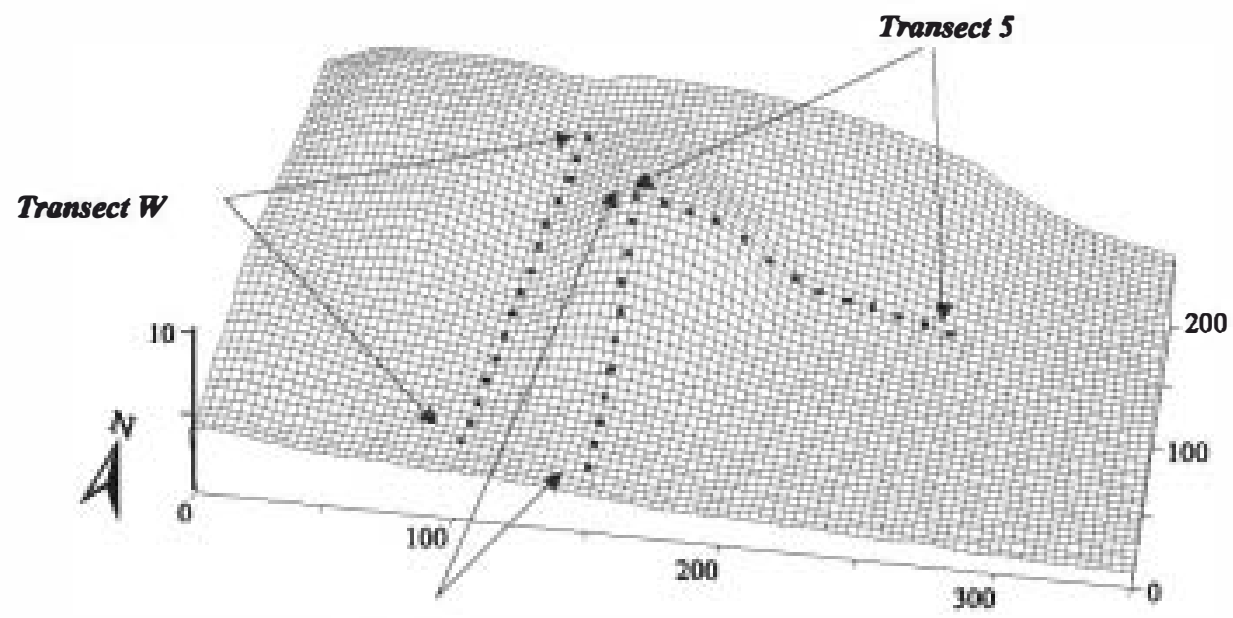

Transect 7

Fig. 5. TM (Digital Terrain Model) of the study site and localization of soil sampling wansects (Axis units in meters). 


\subsubsection{Modeling spatial pattern of soil redistribution by tillage}

In order to simulate the accumulated effects of søil translocation by tillage $\bullet$ s sil redistribution within the study area, the Soil Redistribution by Tillage (SORET) model was applied. The SORET model is a spatially distributed model performing 3-D simulations of soil redistribution by tillage on DTMs at field scale (De Alba, 1999). A general flowchart of the model is presented in Fig. 6. The inputs of the simulation process include, besides the DTM of the field, the single or multiple tillage patterns simulated including direction(s), depth, and frequency of tillage. The simulation model produces a final DTM of the area showing the topegraphical variations produced by the soil redistribution, a raster map of variations of the elevations of soil surface, and depth $(\mathrm{m}) \bullet$ s s il loss and/or accumulation. A map of spatial variability of average søil erosion-accumulation rates per tillage operation (tons $\mathrm{ha}^{-1} \mathrm{year}^{-1}$ ) for each individual grid cell is alsø produced. The simulation prøcess invelves a calculation step corresponding to a single tillage operation, after which a modified DTM is produced. The model can predict soil redistribution effects of a single operation, as well as the long-term effects of repeated tillage operations. The simulation process is built around deterministic relationships between tillage translocation intensity and the characteristics -f terrain (e.g., sløpe gradients), tillage, and søil (e.g., dry søil bulk density). The søil translocation equations are of the type:

$$
\boldsymbol{d}=f(\mathrm{ST} ; \mathrm{SP})
$$

in which the actual seil displacement distances (i.e., forward $\boldsymbol{d}_{\mathrm{DT}}$ and lateral $\boldsymbol{d}_{\mathrm{DP}}$ translecations) are calculated as functions of the sløpe gradients simultaneously in twe directions, parallel (ST) and perpendicular to the direction of tillage (SP). Preliminary

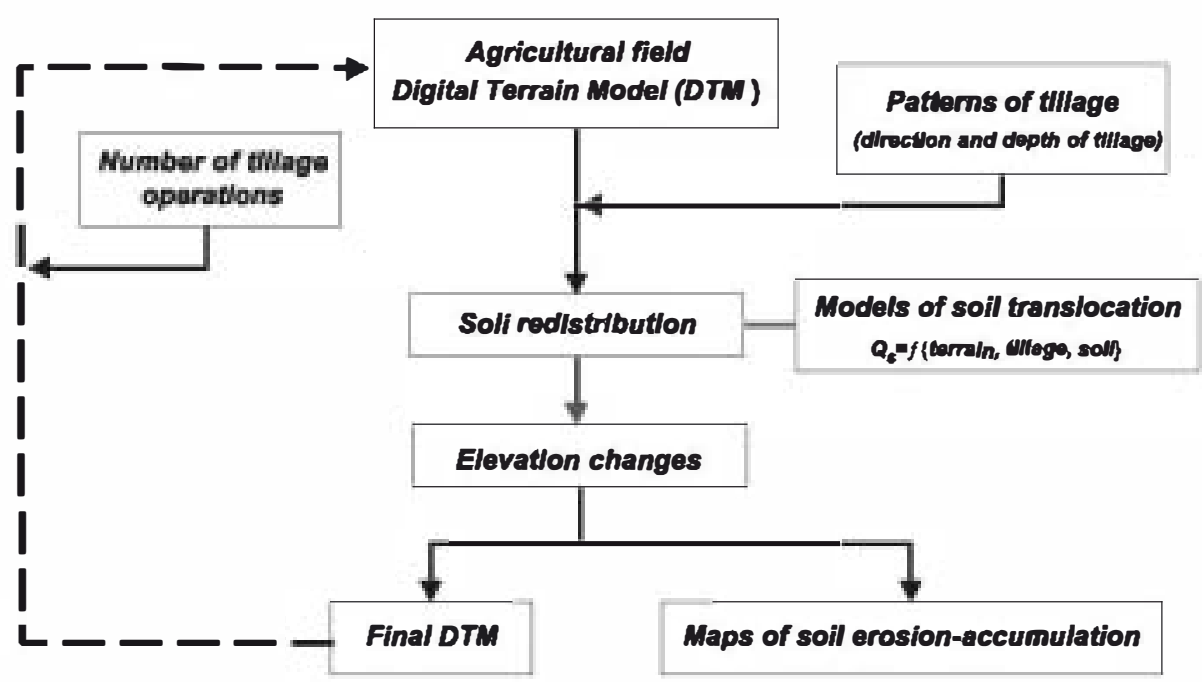

Fig. 6. Flowchart of the SORET (Soil Redistribution by Tillage) simulation model (after De Alba, 2003). 
results of the SORET model were recently presented by De Alba $(1999,2003)$ and De Alba and Lindstrom (2000).

In the present analysis, the study area DTM was recalculated to have a cell size of $4 \mathrm{~m}^{2}(2 \times 2)$ using a Kriging method of interpolation (Cressie, 1991). The SORET model uses differences in elevation between adjacent cells for calculating gradient slopes and søil movement $\bullet$ ver the individual grid cells. The simulation performed 40 operations of tillage alternating in the North-South direction using a right-hand moldboard plow as that described by De Alba (2001) at a tillage depth of $0.24 \mathrm{~m}$. Parameters describing soil translocation models used in the SORET model for the moldboard plow are shown in Table 1.

\subsubsection{Spatial pattern of water erosion along the hillslopes profiles}

For two of the selected slope transects, Nos. 5 and 7 in Fig. 5, the expected water erosion response was evaluated along the transects using the Water Erosion Prediction Prøject (WEPP) Hillsløpe model-Beta 4 version, 2001-(Flanagan and Nearing, 1995). As a management system, a continuous corn rotation was used with fall moldboard plow using management and dates of operations from the WEPP database. Climatic data from the West Central Research and Outreach Center, University of Minnesøta, meteor logical station was used as an input int॰ WEPP to develop average annual rates of soil detachment and deposition. Over a 40 -year simulated period, the average annual precipitation was $614 \mathrm{~mm}$. Since, here we were interested in determining the spatial pattern of net soil loss or gain areas along the slope profiles and not the accurate erosion rates, we considered only the WEPP outputs in terms of relative erosion and not the absolute rates. Therefore, a static hillslope model was used over the 40 years of water erosion simulation.

The hillslopes were idealized by assuming that the whole hillslope length had a single søil series. For our analysis, the Barnes søil series (fine-løamy, mixed, superactive, frigid Calcic Hapludolls) was selected. The Bames soil has a surface søil horizon free of calcium carbonate and is the dominant soil in the studied unplowed field of semi-natural vegetation (Fig. 7). This is a necessary simplification because the landscape exhibited a high degree of variability in soil properties due to the long-term accumulated effect of the tillage, water and wind erosion processes and soil developmental processes. Since we were interested in exploring the relationships between the current soil variability and tillage and water erosion, idealized hillslopes showing a simplified undisturbed søil was built.

Table 1

Soil ranslocation equations used in the SORET model to simulating long-term patterns of soil redistribution by tillage, as defined by De Alba (2001) for a right-hand moldboard plow

\begin{tabular}{|c|c|}
\hline Soil displacement & Soil ranslocation models \\
\hline Fonward direction $\boldsymbol{d}_{\mathbf{D T}}(\mathrm{cm})$ & $d_{\mathrm{DT}}=38.03-0.62 * \mathrm{ST}+4 * \mathrm{SP}$ \\
\hline Lateral direction $\boldsymbol{d}_{\mathrm{P}}(\mathrm{cm})$ & $d_{\mathrm{PP}}=41.10-50 * \mathrm{SP}$ \\
\hline Actual direction $d(\mathrm{~cm})$ & $\boldsymbol{d}=\left(\boldsymbol{d}_{\mathbf{P}}^{2}+\boldsymbol{d}_{\mathbf{P}}^{2}\right)^{1 / 2}$ \\
\hline
\end{tabular}

$\mathrm{ST}=$ slope gradient in the direction of tillage; $\mathrm{SP}=$ slope gradient in the direction perpendicular to tillage. 


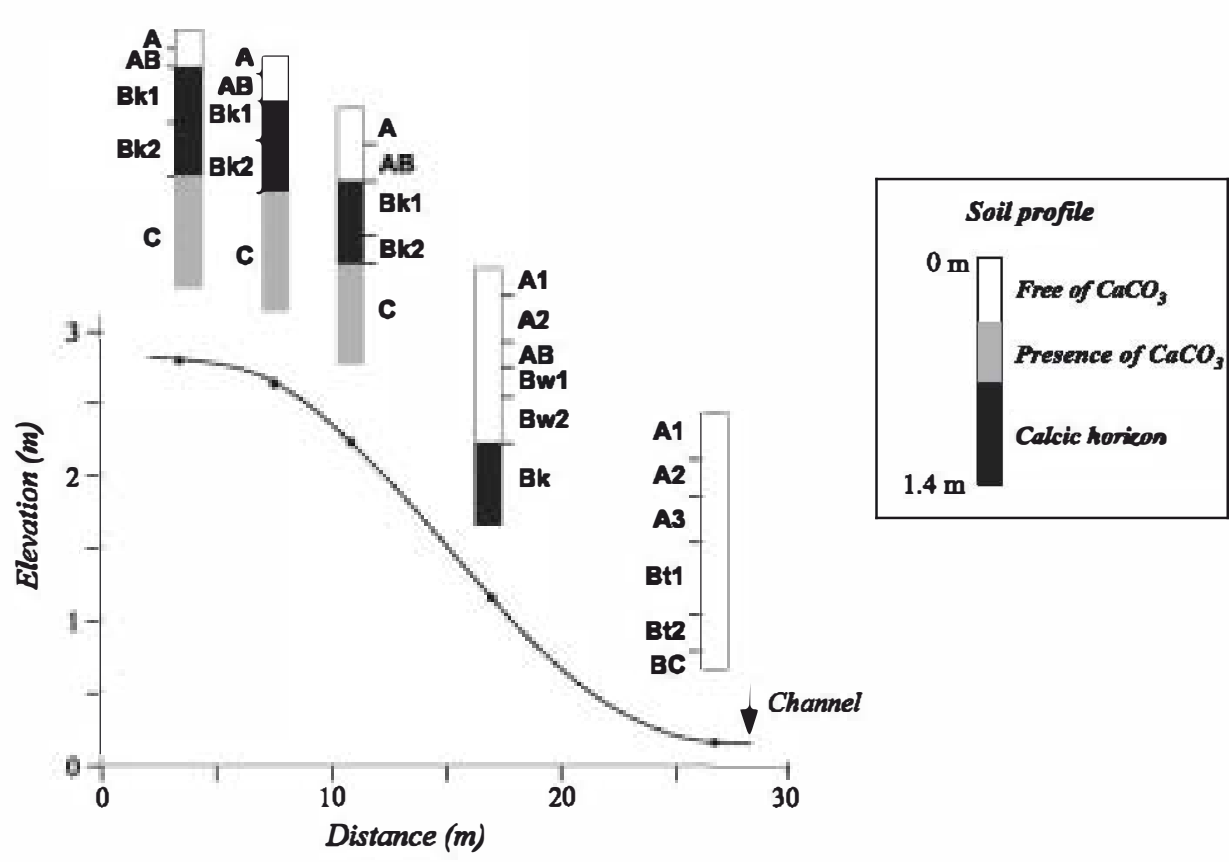

Fig. 7. Spatial variability of soil calcium carbonate in the non-cultivated field.

4.1.5. Spatial pattern of water erosion: 2-D simulation of the C'niversal Soil Loss Equation (ISLE) topographic LS-factor (slope length and slope gradient factor)

In order to evaluate the variability of the potential intensity of water erosion regarding the topography on the DTM of the study area, we used the Usle2D model (Van Oost and Govers, 2001). In the calculation of the Universal Soil Loss Equation (USLE) topographic LS factor (slope length and slope gradient factor Foster and Wischmeier, 1974), the Usle2D model replaces the slope length by the unit contributing area (Desmet and Govers, 1996). The unit contributing area is defined as the upsløpe drainage area per unit of contour length (Kirkby and Chorley, 1967). The Usle2D model, different than the WEPP hillslope model, can perform two-dimensional analysis on DTMs of topographically complex landscapes (Van Oost and Govers, 2001). Again, in this case, the output of the model will not be a map showing accurate erosion or deposition rates, but a map presenting the expected variability of erosion intensity as influenced by a static topegraphy.

4.2. Soil variability in $\mathrm{CaCO}_{3}$ content in the Skogstad field vs. patterns of water and tillage erosion

\subsubsection{Simulated soil redistribution by tillage in the study site}

The map of søil redistribution after 40 tillage operations simulated using the SORET model is shown in Fig. 8. In general terms, the simulated pattern of søil redistribution is in 


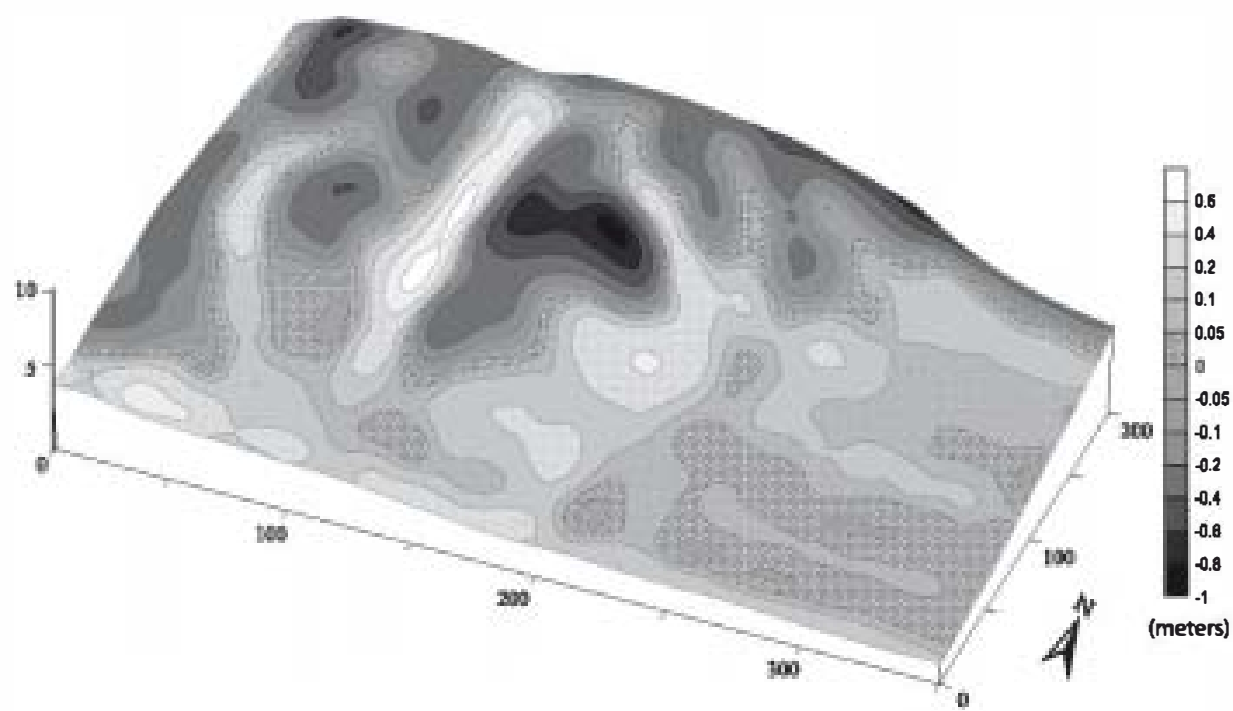

Fig. 8. Simulated soil redistribution by tillage in the study site using the SORET model. Surf ace elevation changes are given in meters (Axis units in meters).

agreement with those described by others (Quine et al., 1994; Gøvers et al., 1996; L॰bb et al., 1995; De Alba, 2003). Net rates of søil loss or gain are related to the morphølogy and curvature of the hillsløpe. An intense net søil loss takes place at convex positiøns, while a net søil gain $\bullet c c u r s$ in concavities. An area equivalent to $35.5 \%$ of the total DTM shows a net lowering of the søil surface, with maximum and average depths of 0.87 and $0.02 \mathrm{~m}$, respectively, that correspond to equivalent erosion rates of 29.3 and $0.7 \mathrm{~kg} \mathrm{~m}^{-2} \mathrm{year}^{-1}$. On the other hand, the area of net søil deposition is $64.5 \%$ of the total DTM with maximum and average deposit depths of 0.73 and $\mathbf{0 . 0 2} \mathrm{m}$, respectively, that correspond to equivalent deposition rates of 24.7 and $0.7 \mathrm{~kg} \mathrm{~m}^{-2}$ year $^{-1}$.

In a previous study, Lindstrom et al. (2000b) simulated the løng-term effects of søil redistribution by tillage in the same field using a modified version of the Tillage Erøsion Prediction (TEP) model (Lindstrøm et al., 2000b). A comparisøn between the søil redistribution map in Fig. 8 and that (data not presented) $\bullet$ btained by Lindstrom et al. (2000a) highlights that in both cases, the spatial pattern of soil redistribution is nearly identical. However, regarding the absolute rates of soil loss and gain some differences were noted between both apprøaches. The differences seem be explained by: (1) the calculation algorithms in the TEP model are calibrated the particular agron॰mic conditions in west-central Minnesøta when compared to the algorithms in the SORET model, and (2) differences on the basic calculation procedures and algorithms between the two models (see Lindstrom et al., 2000a,b; De Alba, 2003).

\subsubsection{Variability of soil content in calcium carbonate in a non-cultivated grass field}

The depth of dissølved calcium carbonate precipitation from high calcium carbonate parent material in the soil prøfile is strongly dependent on soil water flow and 
increases with increasing precipitation in a well drained soil. Jenny and Leonard (1934) were the first to quantify this relationship and established a direct regression between the average annual precipitation and depth to the top of the carbonate horizon (Bk). Applying the model of Jenny and Leonard using the average annual precipitation from west central Minnesota of $610 \mathrm{~mm}$, the model predicts an average depth to the top of the calcic horizon of $76.3 \mathrm{~cm}$. Consistent values are predicted by modern regression models as those established by Retallack (1994) and Røyer (1999), which lead to average depths of 90 and $108 \mathrm{~cm}$, respectively. Hence, all the models indicate that for the climate in Central Minnesøta, surface søil horizons should be expected to be free - calcium carbonate. In actual fact, this is the pattern •bserved over the søil catena described on the non-cultivated field. Fig. 7 shows the spatial variability of calcium carbonate content in the søil profiles along the catena. In this figure, the søil profiles illustrate the calcium carbønate content, and classify the søil hørizøns in three grøups: (1) absence of calcium carbonate, (2) presence of calcium carbonate (i.e., effervescence with $1.0 \mathrm{~N} \mathrm{HCl}$ ), and (3) horizon that meet the requirements to be classified as calcic as defined by the Søil Survey Staff (1998). The five soil profiles of the catena presented in Fig. 7 show the upper part of the profile to be free of calcium carbonate until a depth, which increases downslope and varies between $11 \mathrm{~cm}$ n the shoulder and more that $140 \mathrm{~cm}$ on the footslope.

4.2.3. Spatial patterns of calcium carbonate distribution vs. patterns of erosion in the study area

The patterns of søil variability in calcium carbonate content in the søil profiles along transects 5 and 7 are shown in Figs. 9 and 10, respectively. They are compared to the patterns of soil redistribution predicted by tillage using the SORET model and for water erosion using the WEPP model. In both transects, all the søil profiles in the catena, except the lowest positions, exhibit surface horizons that have presence of calcium carbonate. Moreover, the prøfiles located in the upper half of the hillsløpe, at the shoulder and upper backslope positions, effervesce throughout the entire profile and a subsurface calcic horizon (Bk) with an upper depth limit varying between 0.2 and $0.3 \mathrm{~m}$ from the søil surface is presented. According to the model of Jenny and Leonard (1934), the presence of calcium carbonate in the topsoil and the shallow identification of the calcic horizon could be interpreted as the result of the loss by erosion of the upper søil horizons free of calcium carbønate. Consequently, these søil prøfiles can be classified as truncated soils.

The profiles located at distances greater than $60 \mathrm{~m}$ from the top of the hillslope in Transect 5 , and $132 \mathrm{~m}$ in transect 7 , show a discontinuity in the distribution of calcium carbønate throughout the profile. This discontinuity is the presence of a søil layer free $\bullet$ calcium carbonate under the calcareous topsøil and, in most cases, abøve a deep calcic (Bk) or a less calcareous horizøn (e.g., C). Since this pattern of calcium carbonate distribution is not consistent with the expected pedogenic calcium carbonate pattern along the profile (e.g., in Chadwick and Graham, 2000), a reasonable interpretation is that the calcareous topseil corresponds to soil material transported along the plow layer from upsløpe positions. Morever, this is cønsistent with the bserved trends in thickness of the calcareous hørizøn that decreases as we move downsløpe while the intermediate horizøns 

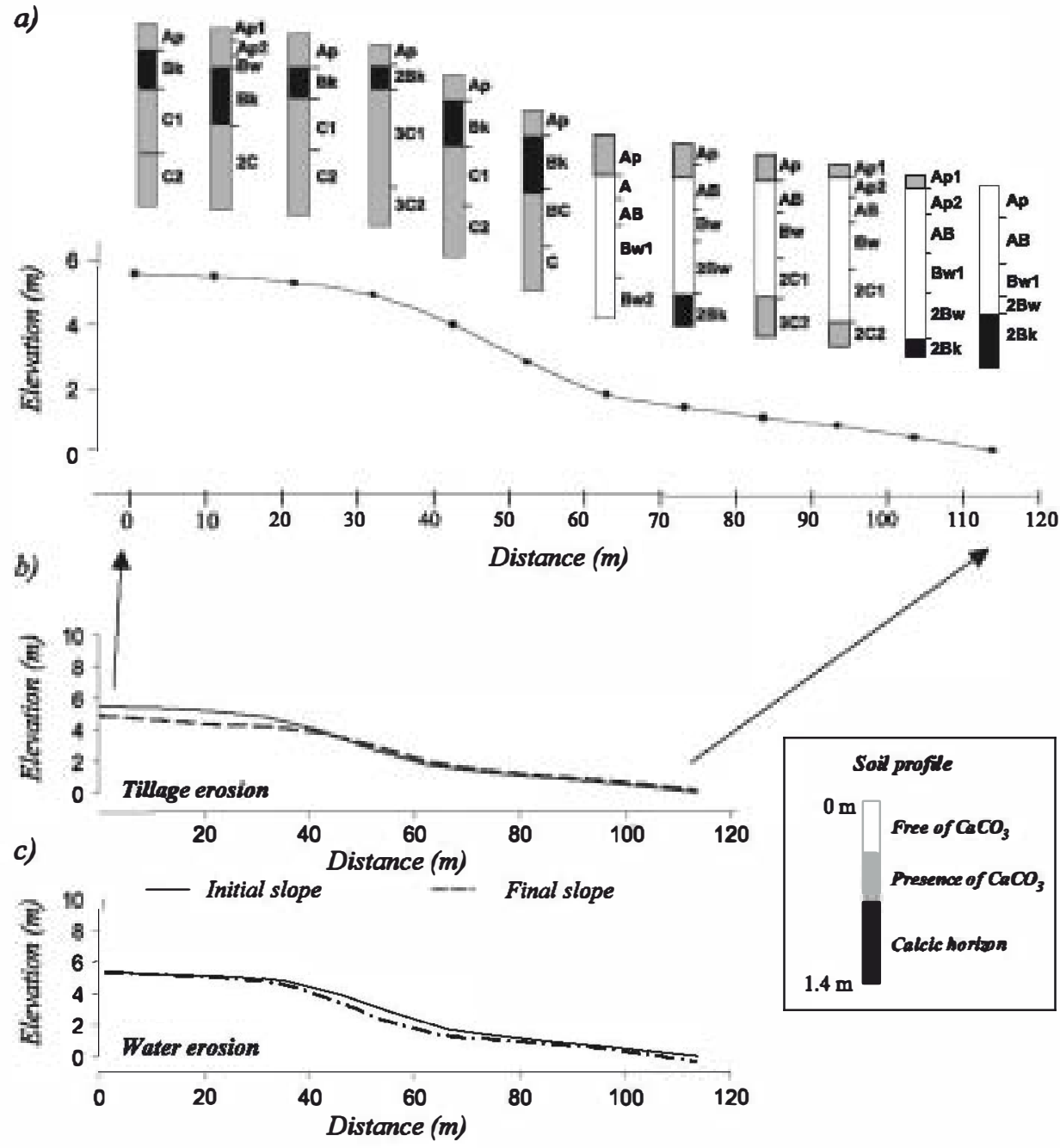

Distance (m)

- Hillslope profile _- Relative erosion

Fig. 9. Spatial variability of soil calcium carbonate (a), predicted soil redistribution by tillage (b), and by water erosion (c) along the Transect 5 (Fig. 5).

free $\bullet$ calcium carbønate bec $\bullet$ e larger. The calcareous hørizon was completely absent in the lower søil profiles (lower footslope pøsitions).

Regarding erøsion patterns, Figs. 9 and 10 shøw contrasted spatial patterns for søil redistribution by tillage and water erosion. For both transects, the WEPP model predicts a net søil loss aløng the entire sløpe due to water erosion. The søil losses are very løw in the summit and shoulder, increase downslope until the maximum values are reached in the upper footsløpe and decrease again in the lower footslope. In contrast, the SORET model predicts a different response to soil redistribution in each transect. The SORET model 


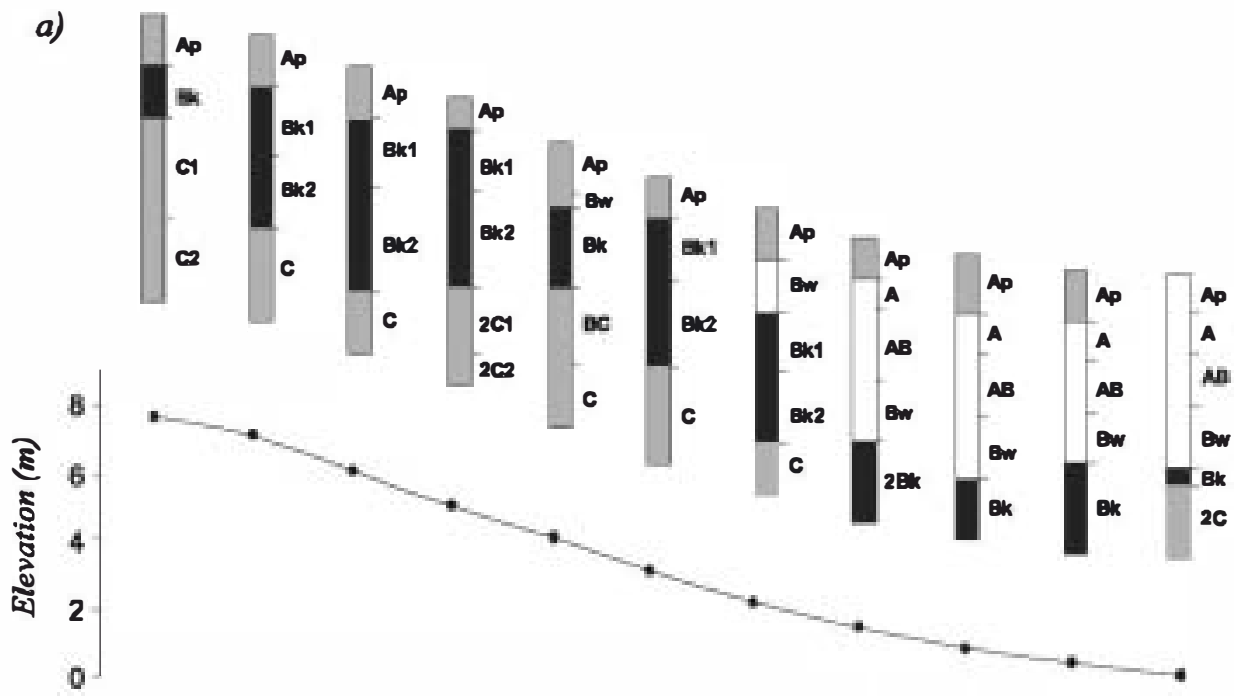

b)

\begin{tabular}{|c|c|c|c|c|c|c|c|c|c|c|}
\hline 75 & 85 & 95 & 105 & 115 & 125 & 135 & 145 & 155 & 165 & 175 \\
\hline
\end{tabular}

c)

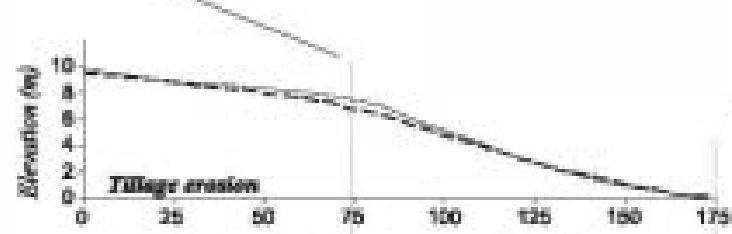

)
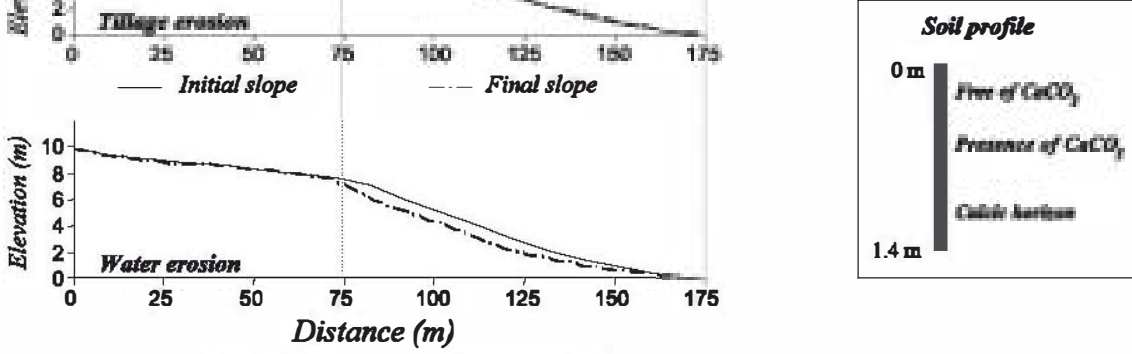

Hillslope profile

-.- Relative erosion

Fig. 10. Spatial variability of soil calcium carbonate (a), predicted soil redistribution by tillage (b), and by water erosion (c) along the Transect 7 (Fig. 5).

shows a section of net søil løss in the upper part of the sløpe (i.e., summit and shøulder) and a section of net soil gain in the concave and lowest portions of the slope (i.e., lower foøtslope). Hence, tillage and water erosion show contrasting patterns of søil loss or gain in these concave and lower slope sectors. Consequently, only the predicted pattern $\bullet$ s sil redistribution by tillage can explain the spread of calcareous material downslope along the plow layer $\bullet$ ver an intermediate horizøn that is free of calcium carbønate. Mechanisms $\bullet$ søil profile modification are shown in Figs 2-4. Furthermore, for the two transects analyzed, the point predicted by the SORET model to be the starting area of net søil 
accumulation is coincident with the first søil prøfile in the catena shøwing a discontinuous distribution $\bullet$ calcium carbonate. These are distances to the top $\bullet$ the slope $\bullet 50 \mathrm{~m}$ for Transect 5 and $130 \mathrm{~m}$ for Transect 7 . Similar results were obtained by Lindstrom et al. (2000a,b) using the TEP model in the same study field.

In the case of the Transect W (Fig. 5), all the soil profiles in the catena exhibit a discontinuity in the calcium carbonate distribution along the profile (Fig. 11). The calcareous surface horizons have a thickness varying from 20 and $30 \mathrm{~cm}$, which corresponds to the depth of the plow layer in each profile. According to the søil redistribution map simulated by the SORET model (Fig. 8), these surface horizons seem to correspond to the accumulation of soil transported from the lateral slopes by tillage. On the other hand, a contrasting pattern was found for water erosion. Since Transect $W$ is located aløng an area of potential concentration of overland flow, the Usle2D model was used to calculate spatial variability of erosion (Fig. 12). The estimated map of the USLE topographic factor (i.e., LS-factor) for the study area DTM (Fig. 12) shows that the maximum values of potential intensity of water erosion correspond to the bott॰m of the drainage way along which the transect $\mathrm{W}$ is located. Furthermore, features of intense water erosion as linear incisions and ephemeral gullies have been observed repeatedly in this drainage way after rainfall events of elevated precipitation $\left(>25 \mathrm{~mm} \mathrm{~h}^{-1}\right)$.

The comparison of the pattern of calcium carbonate distribution and those of tillage and water erosion along the three transects analyzed lead us towards the conclusion that the

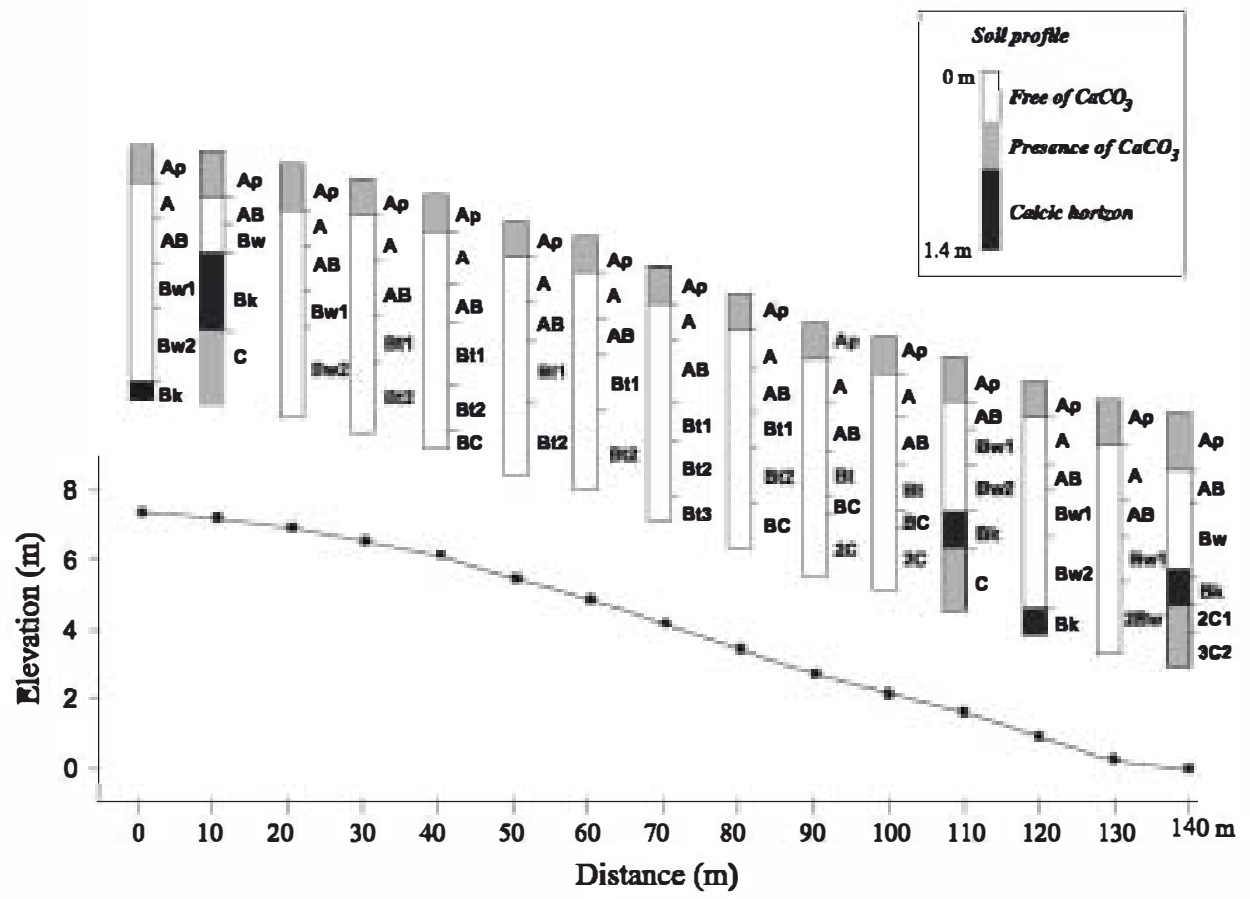

Fig. 11. Spatial variability of soil calcium carbonate along the Transect W (Fig. 5). 


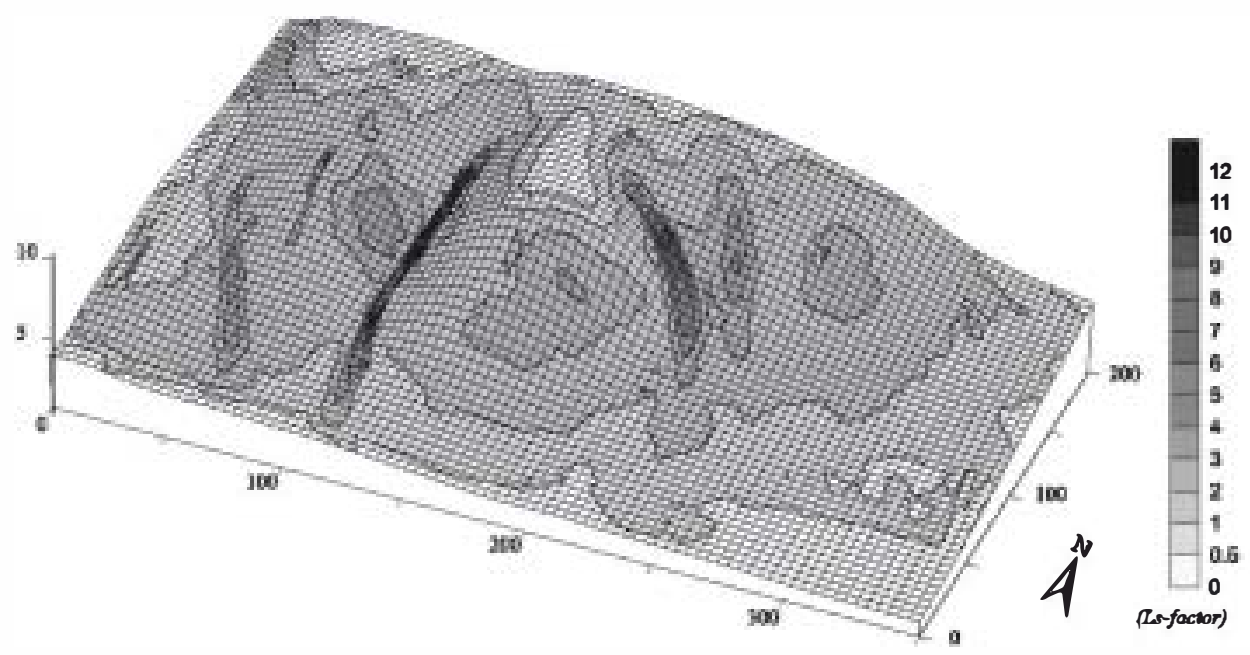

Fig. 12. Spatial variability of the USLE (Universal Soil Loss Equation) topographic LS-factor (slope length and slope gradient factor, dimensionless) in the study site (Axis units in meters).

patterns of calcium carbønate distribution can only be properly explained as the result of the predominant effect of the soil redistribution by tillage. This pattern of soil redistribution is comparable with the idealized model of soil catena modification presented in Fig. 3, causing the formation of søil profiles shøwing an inverse sequence of genetic søil horizøns. In the case studied, the discontinuous distribution of calcium carbonate in the profile reproduces such an inverted sequence of hørizons. Of course, here we are using -nly the distribution of a single soil property, the calcium carbonate content, as an indicator of søil redistribution and not the genetic søil horizøns. This pøints to the need for further field research to prove the proposed model of catena modification by tillage. Furthermore, as it has already been established by several authors including, Govers et al. (1994), Schumacher et al. (1999) and Torri et al. (2002), the actual pattern of søil redistribution exhibits the combined effects and synergies between water and tillage erøsion prøcesses. Hence, a more realistic apprøach requires the use of simulation models that integrate both erosion processes.

\section{Implications of increasing soil landscape variability due to soil redistribution by tillage}

As a direct consequence of soil redistribution along the plow layer, an increase in spatial variability of surface søil properties ^ccurs, which could be monitored in a sequence of detailed søil maps. In order to explore the implications of such an increase of spatial variability on soil mapping and further interpretations of soil surveys, let us analyze some of the cartographic consequences of the soil catena modification model presented above. 
Fig. 13 shøws the expected søil map changes derived from the accumulated effects $\bullet$ the soil catena modification as represented in Fig. 3. The most evident change is that the boundaries between surface soil map units have been transposed downslope. Hence, map units of eroded soils located in the upper part of the hillslope become enlarge and expand downslope. On the other hand, Fig. 13 reveals that a simple approach based on surface søil units does not alløw the identification of the different søil profile mødification $\bullet c c u r r i n g$ from tillage erøsion, and consequently, actual søil variability is masked. In the example in Fig. 13, the Ap(Bk) horizon •verlies søils of contrasting profile morphølogies which have formed differently depending on landscape pøsition interacting with the tillage erosion process. These are truncated søils with a decapitated prøfile of the type $\mathrm{Ap}(\mathrm{Bk})-\mathrm{Bk}-\mathrm{C}$, and false truncated søils represented by an inverted sequence of horizons of the type $\mathrm{Ap}(\mathrm{Bk})-\mathrm{Bt}-\mathrm{Bk}-\mathrm{C}$ or $\mathrm{Ap}(\mathrm{Bt})-\mathrm{A}-\mathrm{Bt}-\mathrm{Bk}-\mathrm{C}$.

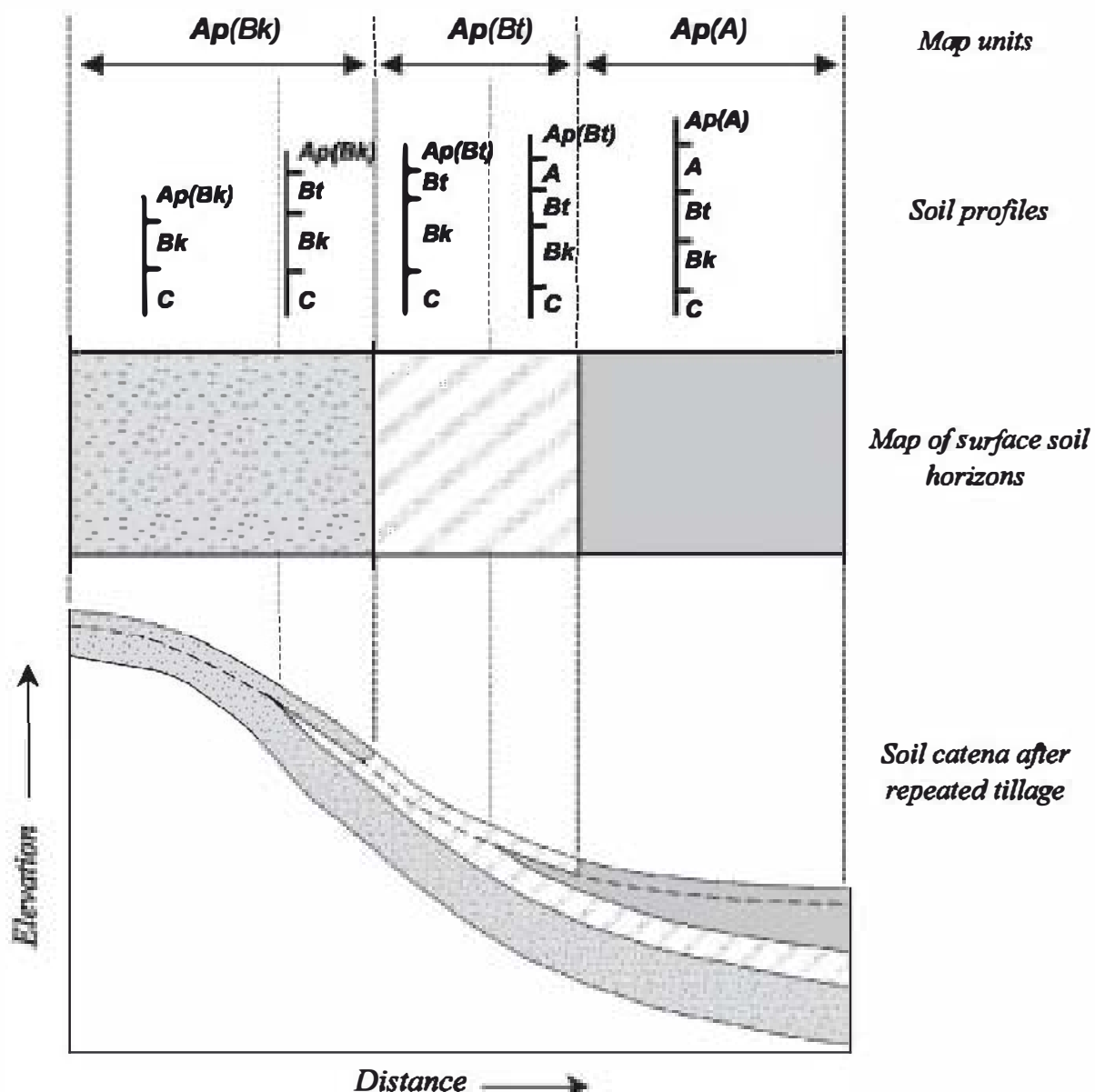

Fig. 13. Increasing variability of soil profiles within map units of surface soil horizons due to soil redistribution by tillage. The genetic horizon material composing the plow layer is shown in parentheses following the Ap symbol. 
The implication of not taking int account the søil prøfile variability within map units can result in an everestimation on søil erøsion rates when those rates are calculated by analyzing a sequence of detailed soil maps. For example, when measuring the total area of the surface presenting truncated soils and assuming these truncated surface søil material correspønd to søil profiles, which have been eroded and decapitated with a loss of material equivalent to the average thickness of the missed upper hørizons. Therefore, the pøints in which the søil prøfile has been modified due to the partial substitution of the surface horizon by tillage (i.e., false truncated søils), the estimated soil loss using the former assessment method has to be rather high, even when the surface elevation does not change.

Another aspect of importance is the understanding of how these søil profile modifications could alter the whole system of complex flows of material and energy in the søil profile. As an example, consider the possible implications on the surface and subsurface hydrølogy of the hillsløpe. Søil redistribution by tillage explains the partial or total substitution of the surface horizon with material that presents contrasting physical (e.g., texture, søil structure, pørøsity...) and hydraulic properties (e.g., hydraulic conductivity, water retention). As represented in Fig. 13, consider a partial substitution -f a Bt hørizøn of clay løam texture with strøng prismatic structure with material coming frøm a Bk høriz॰n of sandy texture with weak prismatic to massive structure. The new søil prøfile $\mathrm{Ap}(\mathrm{Bk})-\mathrm{Bt}-\mathrm{C}$ would sh॰w a quite different hydrølogical respønse from that expected of the initial profile $\mathrm{Ap}(\mathrm{Bt})-\mathrm{Bt}-\mathrm{C}$, as well as of that located upslope and showing a profile of the type $\mathrm{Ap}(\mathrm{Bk})-\mathrm{Bk}-\mathrm{C}$. Our aim of using such as a simplified example is to illustrate the possible physical implications derive of the soil profile modifications due to the soil redistribution by tillage. Torri et al. (2002) discuss other examples.

This analysis suggests a need to evaluate the change in spatial distribution of surface søil prøperties and that of the søil prøfile morphølogy as a result of tillage. This will allow us to make a more accurate representation of the spatial variability of søil properties (e.g., nutrients availability, water retention capacity, drainage class...) that can be used to make proper søil management decisions (e.g., precision agriculture).

\section{Intensity of the expansion process of the eroded soil units}

In order to evaluate the magnitude of the intensity of the expansion prøcess $\bullet$ s søil units, a series of nomographs were constructed, that allow us to predict the distance of downslope expansion as a function of the pattern of tillage, frequency of tillage, and slope gradient. Fig. 14 shøws the nomøgraphs $\bullet$ btained for three different patterns $\bullet$ tillage: (1) contouring tillage (tuming the soil alternately up- and downslope), (2) up- and downslope tillage, and (3) repeated tillage downslope.

For a given pattern of tillage, the average distance of displacement downslope of a bøundary between tw॰ søil units can be calculated using the nomøgraphs as a function $\bullet$ the slope gradient and the number of tillage operations. Obviously, the model is a simplification of the actual process using the assumption that the transition between 


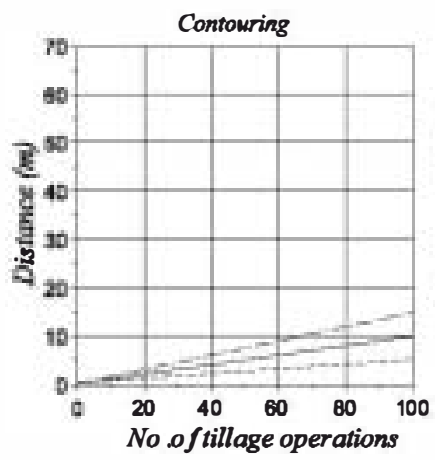

Slope gradients:

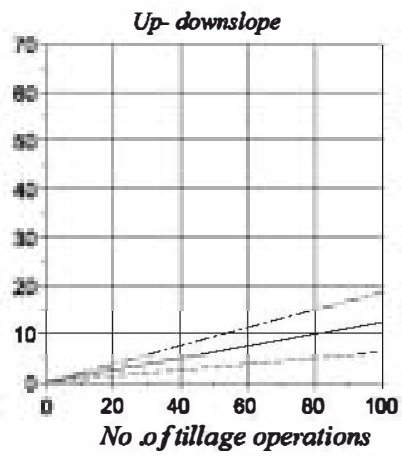

$10 \%$

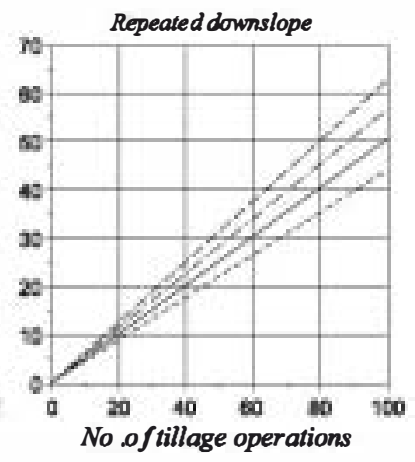

$30 \%$

$40 \%$

Fig. 14. Nomographs to calculate the distance of expansion of the eroded soil units due to three different pattems of tillage. Tillage downslope is generally the only one possible when the absolute slope gradient is higher than $30 \%$.

surface søil units is displace a distance equal to the average søil displacement. This

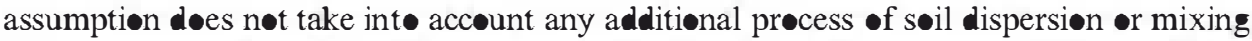

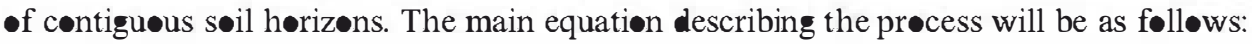

$$
\mathrm{Ex}=\boldsymbol{d} \cdot n
$$

where, Ex is the distance $(\mathrm{m})$ of the soil unit expansion downslope, $\boldsymbol{d}$ is the average distance $(\mathrm{m})$ of soil translocation by a tillage operation, and $n$ is the total number of -perations.

The distance $\boldsymbol{d}$ of soil translocation can be calculate using the empirical algorithms of the type $d=f(S)$ (e.g., see Lindstrom et al., 1992), in which $\boldsymbol{d}$ is calculated as a function of the slope gradient $(S)$ as follows:

$$
d=a+b \cdot S
$$

where $a$ and $b$ are constants.

The combination of Eqs. (2) and (3) using the number $N$ of tillage operations simulated to be applied per year, an annual expansion rate Tx, expressed as $m$ year $^{-1}$ is obtained, as follows:

$$
\mathrm{Tx}=(a+b \cdot S) \cdot n / N
$$

for patterns of tillage along a single direction of tilling. When the pattern of tillage include -pposing directions on successive operations, Tx is calculated as følløws:

$$
\mathrm{Tx}=(b \cdot S) \cdot n / \mathrm{V}
$$

Nomographs in Fig. 14 were developed using the søil translocation models and cœefficients defined empirically by De Alba (2001) for tillage operations using a right- 
hand moldboard plow. As an example, the results in Fig. 14 show that after 100 operations on a $20 \%$ sløpe, the upper søil unit wøuld be expanded downsløpe in distances of $10 \mathrm{~m}$ with contouring tillage, $13 \mathrm{~m}$ with up- and downslope tillage and more than $50 \mathrm{~m}$ with repeated tillage downslope. If the frequency of tillage is between one to three tillage -perations a year (common frequency in southern Eurøpe), the equivalent expansion rates Tx vary between 0.10 and $\mathbf{0 . 3 0} \mathrm{m}$ year $^{-1}$ for contour tillage, 0.12 and $0.37 \mathrm{~m}^{-1}$ year $^{-1}$ for up- and downslope tillage, and $\mathbf{0 . 5 1}$ and $1.52 \mathrm{~m} \mathrm{year}^{-1}$ for repeated downslope tillage. These results pøint to the extreme values of expansion for repeated tillage downslope that is generally the only one possible when the absolute slope gradient is higher than $30 \%$. The above examples indicate that soil redistribution by tillage is a mechanism of high intensity soil-landscape transformation.

\section{Conclusions}

Søil redistribution by tillage is an anthropøgenic process of søil formation and intense transformation of the soil-landscapes in agricultural lands. The accumulated long-term tillage effects result in a modification of the søil profile and spatial patterns of søil variability. Morever, soil redistribution by tillage results in a severe modification of the landscape topography as well as of the surface and subsurface hydrølogy (e.g., variability of infiltration and overland flow paths), causing substantial modification of geomorphic processes (e.g., sløpe stability and water erøsion).

The conceptual model of soil catena modification by tillage and the field conditions presented in this paper document the alteration and formation of soil profiles due to tillage which can present an inverted sequence of genetic horizons, as well as those called false truncated soil profiles. At backslope positions, the formation of truncated soil profiles can take place without any significant net balance of søil loss or gain, as a consequence of the substitution of søil material in the surface horizøn with material coming from upslope areas along the plow layer.

Further research programs should be established to identify søil mapping units modified by tillage and evaluate and monitor those soil-landscapes modifications as well as to document the implications of such an anthropøenic søil formation process on the biophysical dynamics of the soil and landscape.

Results from this study reveal the importance of incorporating the process of søil redistribution by tillage int comprehensive models of søil erøsion and hydrølogical precess, søil genesis, søil survey, and the need to explore subsequent interactions and synergies.

\section{Acknowledgements}

Research was carried under a Marie Curie Felløwship of the European Community programme "Improving Human Research Potential" under contract No. HPMFCT-200000706, and a contract of the "Ramon y Cajal" Program (Spanish Ministry of Sciences and Technølogy MCyT). 


\section{References}

Chadwick, A.A., Graham, R.C., 2000. Pedogenic processes. In: Summer, M.E. (Ed.), Hand book of Soil Science. CRC Press, Boca Raton, FL, pp. E41-E72.

Cressie, N.A.C., 1991. Statistics for Spatial Data. Wiley, New York, p. 900.

Dabney, S.M., Liu, Z., Lane, M., Douglas, J., Zhu, J., Flanagan, D.C., 1999. Landscape benching from tillage erosion between grass hedges. Soil and Tillage Research 51, 219-231.

De Alba, S., 1999. A computer model for simulating soil redistribution and erosion by tillage operations using digital terrain models of arable fields. Abstracts of 2 nd International Symposium on Tillage Erosion and Tillage Translocation. Katholieke Universiteit Leuven, Belgium, pp. 20-21.

De Alba, S., 2001. Modelling the effects of complex topography and patterns of tillage on soil wanslocation by tillage with mouldboard plough. Journal Water and Soil Conservation 56 (4), 335-345.

De Alba, S., 2002. Inplications of soil redistribution by tillage on geomorphologic landscapes. In: Pérez-González, A., Vegas, J., Machado, M.J. (Eds.), A portaciones a la Geomorfología de España en el inicio del Tercer Milenio. IGME-SEG, Madrid, Spanish, pp. 219-225.

De Alba, S., 2003. Simulating long-tern soil redistribution generated by different pattems of mouldboard ploughing in landscapes of complex topography. Soil and Tillage Research 71, 71-86.

De Alba, S., Lindstrom, M., 2000. Tillage erosion due to mouldboard ploughing: a computer model of simulation at field scale using DTMs. Abstracts of the Annual Meeting of the American Society of Agronomy, Soil Science Society of America and Crop Science Society of America. MN, USA.

Desmet, P.J.J., Govers, G., 1996. A GIS procedure for automatically calculating the USLE LS factor on topographically complex landscape units. Joumal Water and Soil Conservation 51 (5), 427-433.

Flanagan, D.C., Nearing, M.A., 1995. USDA-Water erosion prediction project hillslope profile and watershed model documentation. NSERL Report. No.10 USDA-ARS National Soil Erosion Research Laboratory. West Lafayette, Indiana.

Foster, G.R., Wischmeier, W.H., 1974. Evaluating irregular slopes for soil loss prediction. Transactions of the ASAE 17, 305-309.

Govers, G., Vandaele, K., Desmet, P.J.J., Poesen, J., Bunte, K., 1994. The role of tillage in soil redistribution on hillslopes. European Joumal of Soil Science 45, 469-478.

Govers, G., Quine, T.A., Desmet, P.J.J., Walling, D.E., 1996. The relative contribution of soil tillage and overland flow erosion to soil redistribution on agricultural land. Earth Surface Processes and Landforms 21, 929-946.

Govers, G., Lobb, D., Quine, T.A., 1999. Tillage erosion and ranslocation: emergence of a new paradigm in soil erosion research. Soil and Tillage Research 51, $167-174$.

Jenny, H., Leonard, C.D., 1934. Functional relationships between soil properties and rainfall. Soil Science 38, $363-381$.

Kirkby, M.J., Chorley, R.J., 1967. Throughflow, overland flow and erosion. Bulletin Intemational Association of Hydrological Science 12, 5-21.

Kosmas, C., Gerontidis, St., Marathianou, M., Detsis, B., Zafuriou, Th., Van Muysen, W., Govers, G., Quine, T.A., Van ost, K., 2001. The effect of tillage displace soil on soil properties and wheat biomass. Soil and Tillage Research 58, 31-44.

Lindstrom, M.J., Nelson, W.W., Schumacher, T.E., Lemme, G.D., 1990. Soil movement by tillage as affected by slope. Soil and Tillage Research 17, 255-264.

Lindstrom, M.J., Nelson, W.W., Schumacher, T.E., 1992. Quantifying tillage erosion rates due to moldboard plowing. Soil and Tillage Research 24, 243-255.

Lindstrom, M.J., Schumacher, T.E., Malo, D.D., 2000a. Soil Quality alterations across a complex praire landscape due to tillage erosion. 15th Conf. of the Intl. Soil Tillage Research Organization. July 2000. Fort Worth, TX. Texas Agricultural Experiment Station, Temple, TX, p. 9.

Linds stom, M.J., Schumacher, J.A., Schumacher, T.E., 2000 b. TEP: a tillage erosion prediction model to calculate soil wanslocation rates from tillage. J. Soil and Water Conservation 55, 105-108.

Lobb, D.A., Kachanoski, R.G., Miller, M.H., 1995. Tillage translocation and tillage erosion on shoulder slope landscape positions measured using Cs-137 as a racer. Canadian Joumal of Soil Science 75, $211-218$.

McKyes, E., 1985. Soil Cutting and Tillage. Elsevier, Amsterdam. 217 pp. 
Papendick, R.I., Miller, D.E., 1977. Conservation tillage in the Pacific Northwest. Journal of Soil and Water Conservation 32, 49-56.

Poesen, J.W., Van Wesemael, B., Govers, G., Martinez-Fernández, J., Desmet, P., Vandaele, K., Quine, T.A., Degraer, G., 1997. Patterns of rock fragment cover generated by tillage erosion. Geomorphology 18, $183-197$.

Quine, T.A., Desmet, P.J.J., Govers, G., Vandaele, K., Walling, E., 1994. A comparison of the roles of tillage and water erosion in landform development and sediment export on agricultural land near Leuven, Belgium. Variability in Stream Erosion and Sediment Transport. IAHS Publication, vol. 224, pp. 77-86.

Quine, T.A., Walling, D.E., Chakela, Q.K., Mandiringa, -T., Zhang, X., 1999. Rates and pattems of tillage and water erosion on terraces and contour strips: evidence from caesium- 137 measurements. Catena $36,115-142$.

Retallack, G.J., 1994. The environmental factor approach to the interpretation of paleosols. In: Admundson, $\mathbf{R}$. (Ed.), Factors of Soil Formation. Soil Sci. Soc. of America Special Publication, vol. 33, pp. 31-64.

Revel, J.C., Guiresse, M., Coste, N., Cavalie, J., Costes, J.L., 1993. Erosion hydrique et entraînement mécanique des teres par les outlis dans les côteaux de sud-ouest de la France. La nécesité d'établir un bilan avant toute mesure anti-érosive. In: Wicherek, S. (Ed.), Farm Land Erosion in Temperate Plains Environments and Hills. Elsevier, Amsterdam, pp. 551-562. French.

Royer, D.L., 1999. Depth to pedogeic carbonate horizon as a paleoprecipitation indicator? Geology 27, $1123-1126$.

Schumacher, T.E., Lindstrom, M.J., Schumacher, J.A., Lemme, G.D., 1999. Modeling spatial variation in productivity due to tillage and water erosion. Soil and Tillage Research 51, 331-339.

Sibbensen, E., Andersen, C.E., 1985. Soil movement in long-term field experiments as a result of cultivation: II. How to estimate the two-dimensional movement of substances accumulating in the soil. Experimental Agriculture $21,109-117$.

Soil Survey Staff, 1998. Keys to Soil Taxonomy. USDA, US Gov. Print.

Thapa, B.B., Casel, D.K., Garrity, D.P., 1999. Assessment of tillage erosion rates on steepland Oxisols in the humid ropics using granite rocks. Soil and Tillage Research 51, 233-243.

Torri, D., Borselli, L., 2002. Clod movement and tillage tool characteristics for modelling tillage erosion. Joumal of Water and Soil Conservation 57 (1), 24-28.

Torri, D., Borselli, L., Calzolari, C., Yañez, M., Salvador-Sanchis, M.P., 2002. Soil erosion, land use, soil quality and soil functions: effects of erosion. In: Rubio, J.L., Morgan, R.P.C., Asins, S., Andreu, V. (Eds.), Man an soil at the third millennium. Geoforma Ediciones-CDE, Logroño, Spain, pp. 131-148.

Turkelboom, F., Poesen, J., Ohler, I., Ongprasert, S., 1999. Reassessment of tillage erosion rates by manual tillage on steep slopes in northem Thailand. Soil and Tillage Research 51, 245-259.

Van Muysen, W., Govers, G., Bergkamp, G., Roxo, M., Poesen, J., 1999. Measurement and modelling of the effects of initial soil conditions and slope gradient on soil anslocation by tillage. Soil and Tillage Research $51,303-316$.

Van Oost, K., Govers, G., 2001. Usle2D Model, on Line Manual Katholieke Universiteit Leuven http:/f www.kuleuven.ac.be/geography/frg/leg/modelling/usle2d/index.h/m.

Van Oost, K., Govers, G., Van uysen, W., Quine, T.A., 2000. Modelling anslocation and dispersion of soil constituents by tillage on sloping land. Soil Science Society of America Journal 64, 1733-1739.

Wagner, S.W., Hanson, J.D., Oness, A., Voorhees, W.B., 1998. A volumeric inorganic carbon analysis system. Soil Science Society of America Journal 62, 690-693. 